\title{
The Cost of Coalition Compromise: The Electoral Effects of Holding Salient Portfolios
}

\author{
Zachary Greene, University of Strathclyde \\ Nathan Henceroth, Albright College \\ Christian Jensen, University of Nevada, Las Vegas
}

This article highlights the electoral effects of holding salient portfolios within a coalition government. For voters, holding ministries can be seen as a symbol of a party's success within the coalition. As a voting heuristic, parties not controlling the portfolios on issues important to their platforms signal their failure to achieve these goals. Following this perspective, we hypothesize that the difference between coalition parties that hold salient portfolios and those that do not partially predicts the extent of the electoral cost of coalition participation. Using a dataset that covers 11 European parliamentary democracies between 1966 and 2002, we show that for junior coalition partners there is an electoral reward for holding their most salient portfolio. There is also an electoral benefit for a junior partner to hold a larger number of portfolios if they do not control their most salient portfolio. Conversely, holding their most salient portfolio and a larger number of additional ministries results in greater electoral losses in the subsequent parliamentary election. These results indicate that parties' success at negotiating for their policy priorities in coalition governments holds consequences for their future electoral success.

Key words: Coalition Governance, Elections, Issue Salience, Policy Responsiveness, Policy Accountability, Portfolio Allocation 


\section{Introduction}

Incumbents in coalition governments generally suffer electoral costs for their participation in subsequent parliamentary elections. Coalition parties such as the Liberal Democrats in the 2010 British governing cabinet and the Free Democratic Party in the 2012 German cabinet suffered disproportionate electoral costs. Yet, parties routinely seek to enter into governing coalitions, trading off future electoral benefits for current government influence. This article investigates how parties can mitigate these electoral costs. Furthermore, how can coalition parties signal success to their supporters while avoiding being held electorally accountable for the costs of governing? In both the British and German cases, the larger coalition partners even benefited from their junior coalition partners' demise (see Fortunato and Stevenson 2013a; Adams et al. 2015; Fortunato and Adams 2015; Meyer and Strobl 2016; Spoon and Klüver 2016). Strategies to manage their future electoral success while minimizing the cost of coalition participation would allow parties to satisfy their policy and office seeking goals while mitigating their predicted electoral losses in the next election.

In this study, we reconsider the costs of coalition participation, and examine how coalition parties can minimize predicted electoral losses by possessing salient portfolios as a sign of party competence to their constituencies. Of particular interest are smaller parties that join coalitions as junior partners. While these parties are often mainstream parties, they are not in contention to control the Prime Minister (PM). Additionally, junior partners are generally smaller parties in both vote share and members of parliament, and they often hold a more limited set of issue appeals (Greene 2017).

Studies of coalition governance highlight the role of ministers as the most prominent symbols of coalition parties' priorities in coalition negotiations (see Bäck et al. 2011). As 
symbols of the parties' performances, we suggest that voters use portfolios to evaluate and to hold accountable governing coalition parties' successes and failures. From this perspective, voters perceive that parties controlling portfolios linked to their most salient issues as more successful and competent. The electoral costs of coalition participation, therefore, are partially determined by the parties' ability to control the portfolios of their policy priorities.

We develop our theory by combining research on coalition participation (see Strom et al 2008) with indicators of parties' electoral priorities derived from parties' manifestos (see Volkens et al. 2011). We expect that there is a cost in not controlling the public symbol of policy-making. Furthermore, this theory addresses the complicated process through which voters evaluate parties in contexts of low clarity of accountability (Powell and Whitten 1993; Whitten and Palmer 1999). By combining theories of portfolio ownership, electoral accountability, and issue competition, we find evidence consistent with the notion that voters will adapt to complex institutional settings and will hold their parties accountable for perceived failure (see Fortunato and Stevenson 2013b). As a heuristic of party success, cabinet positions offer coalition parties both policy-making influence and the possibility to avoid catastrophic electoral defeat in subsequent elections.

\section{Holding Governing Parties Accountable}

Much has been written on the electoral costs incumbent parties pay in parliamentary elections, yet parties still routinely seek to enter into governing coalitions. ${ }^{1}$ Parties have agency, however, and they can develop election campaigns to combat their expected electoral losses. We would suggest that parties will be able to satisfy their policy and office seeking goals, while

\footnotetext{
${ }^{1}$ For more on this debate, see Axelrod 1970, Strom 1990, and Laver and Schofield 1990.
} 
minimizing their predicted electoral losses in the next election, by signaling to voters that they have been successful in obtaining their salient portfolios. Party loyalists, in turn, reward portfolio ownership in the subsequent election. While this approach may not be sustainable over the longterm, it can allow parties to enter into a governing coalition while staving off the costs of governing in the short-term. The routine occurrence of minority government coalitions throughout Europe can be interpreted as smaller parties viewing the cost of governing as greater than the expected utility of possible future portfolio procurement (Strom 1984; 1990). Once a party has chosen to join a coalition, however, if it is able to control its most salient portfolio this can be seen as a political victory for the party's core constituents.

The cost of governing is not a new phenomenon. Previous research on the electoral price that incumbent parties pay at the polls has demonstrated a clear link between governing and a diminished vote share in subsequent parliamentary elections (Rose and Mackie 1983; Paldam 1986; Narud and Valen 2008; Bergman and Strom 2011). On the other hand, economic voting literature has shown how economic determinants such as GDP, inflation, and unemployment rates can affect governing parties in either a positive or negative fashion (Lewis-Beck 1986; Nannestad and Paldam 1994; Lewis-Beck and Stegmaier 2000; 2013; Hjermitslev 2018). Additionally, recent research on the electoral effect of holding a ministerial office in Ireland found that individual politicians who held a portfolio received an electoral boost over copartisans who did not hold a ministerial office (Martin 2016). Moreover, research into how German and Italian voters attribute responsibility in coalition governments found that while the Prime Minister party receives the brunt of the blame for government failures or the rewards of government successes in Germany (see Debus et al. 2014), other factors play a role in how the Italian electorate assigns blame to smaller coalition parties (Plescia 2017). If parties face a 
predictable cost of governing, they can seek to mitigate their electoral losses by obtaining desirable portfolios and signaling to their constituency their success in much the same way that a Prime Minister's party campaigns on the success of a robust economy.

Government formation research suggests that the logical goal of a potential coalition party is to maximize its utility by increasing influence. The focus of this bargaining among coalition partners is the allocation of cabinet portfolios (Warwick and Druckman 2001; Druckman and Warwick 2005; Proksch and Slapin 2006; Carroll and Cox 2007; Bäck et al, 2011). Further research extends this bargaining logic to include the salience of particular portfolios to particular parties. Bäck et al (2011) found a significant relationship between portfolio assignment and ideological party family. Greene and Jensen (2016) found that parties assign junior ministers to oversee coalition partners in ministries that are salient to them. Greene and Jensen (2018) add that ideological disagreement on the corresponding issue dimensions moderates the effect of issue salience on ministerial assignments. The findings in these works underscore the importance of focusing on ministers as preference outliers that need to be constrained by their own coalition partners (see Indridason and Kam 2008; Indridason and Kristinsson 2013; Kim and Lowenberg 2005; Lipsmeyer and Pierce 2011; Thies 2011)..

While voters are unlikely to be aware of the constraints that parties face while negotiating portfolio allocations, they are capable of picking up on patterns of coalition formation. As Debus and Müller (2014) demonstrate, German voters were able to pick up on patterns that emerge from coalition formation. Even if ministers are not so powerful to act as dictators in their policy jurisdictions (e.g. Laver and Shepsle 1996), cabinet positions represent prominent and public indicators of the benefits a party received in return for joining a coalition government. 
Following this logic, a party's success at negotiating their preferred portfolios within a governing coalition makes for a simple heuristic to voters.

The relative location of parties' preferences and their issue priorities hold important consequences for coalition negotiations and termination, as well. Along with the portfolios they control, even the documents they produce to outline their collective agreements act as public symbols of the coalition parties' policy-making payoffs (Eichorst 2014). Indeed, these symbols should matter as parties construct election campaigns on the issues that matter. In this light, we also expect party loyalists, and potential supporters, to value the total number of portfolios their party receives. This would signal a seriousness about governing that reinforces party loyalty in the subsequent election.

\section{How Issue Competition Leads to Electoral Accountability}

Parties compete in elections on the issues they emphasize. Theories of issue competition emphasize parties' strategic calculations to mobilize core constituencies and underline their policy competencies (see Robertson 1976; Carmines and Stimson 1986; Cole 2005; GreenPedersen 2007). For our theory, the inability of coalition partners to obtain their most salient portfolios can be a clear signal of incompetence to their supporters. In other words, after coalition parties have stressed to their loyalists and potential party supporters the importance of certain issues, not obtaining relevant portfolios sends a message of failure to their voters.

Parties benefit from emphasizing issues on which they have a positive historical link and reputation (Petrocik 1996). Issue ownership is often conceptually tied to perceptions of parties' policy competencies. Particularly for smaller parties that tend to have a stronger focus on a single issue, this ownership can be signaled to party loyalists via portfolio allocation within a coalition. 
Moreover, voters can also hold associative perceptions of parties. Previous research has found that voters are able to link certain issues to parties regardless of a party's ability to influence policy on that dimension (Walgrave et al. 2012, 2014; Tresch et al. 2013). Ultimately, voters form these perceptions from parties' past experiences in government (Egan 2013), and while factors such as the economy also influence voters' perceptions of parties' governing competencies (Green and Jennings 2012), we assert that controlling salient portfolios is the clearest signal of competence a minor coalition partner can send to its constituencies. If voters are primed to associate a certain issue with a party, even in instances where the party has no policy influence, we expect that when these parties join a coalition they stand to benefit from the competence signaled by their control of portfolios associated with issues salient to their supporters.

When parties enter into office, numerous factors limit their ability to implement policies on these issues (Green-Pedersen and Mortensen 2009). Yet, the policies governments address in office likely correspond to the issues important in the governing parties campaigns (Thomson 2001; Soroka and Wlezien 2010; Bevan and Greene 2016, 2017). Presumably, governments implement policies on the issues they campaigned on to appear accountable to voters (Carey 2007). From this perspective, parties that ignore their policy pledges will be punished by voters in future elections (Downs 1957; Carey 2007; Mansergh and Thomson 2007).

Voters' ability to hold governments accountable for their policy activities is limited, though. Even the most educated voters are unlikely to know the details of governments' policy activities in complex coalition environments (Whitten and Palmer 1999). A program-to-policy accountability or responsiveness perspective would require that voters form strong perceptions of governments' promises and policy-making. Although voters often pay attention to the most 
important campaign promises (Thomson 2011), they likely rely on shortcuts or symbols to stay informed. Broad factors such as the economy may provide information about the government's broad commitment to managing the country (Lewis-Beck and Stegmeier 2000; Anderson 2007), but outward symbols such as a party controlling a minister can serve as a clear heuristic of their policy-making priorities, and their competence as a political party.

\section{Portfolios as Symbols of Accountability and Responsiveness}

The logic of the cost of governing argument is that the act of governing involves policy trade-offs and compromises that lead to electoral losses in the subsequent election. Parties in government must meet the high expectations of their constituents. Appearing weak or ineffective as a government participant exacerbates constituents' frustrations with their party leaders and may lead to diminished electoral support in the next election. However, parties that appear strong and effective may be able to mitigate these electoral losses. One way to do that would be to control a lot of ministries. Consistent with Gamson's Law, existing research suggests that, while not perfect, there will be a correlation between the number of ministries a party will hold and that party's seat share (Laver and Shepsle 1996; Falcó-Gimeno and Indridason 2013). It stands to reason, however, that coalition parties will try to lessen their expected electoral losses as much possible.

It further stands to reason that demonstrating party competence, by possessing salient portfolios, signals to a party's constituents that it is worthy of support during the next election. When a party makes a particular issue area a priority in the campaign, their constituents expect them to take action in that area if they are elected. Controlling salient portfolios would be a highly visible and effective way to demonstrate such action. Conversely, failing to control a 
highly salient ministry could be seen as a sign of profound party ineptitude. Imagine a green party that enters into a coalition, but fails to control the environment ministry. This could be seen as a result of poor bargaining skills on the part of the party leadership if not an outright betrayal of core party principles regardless of behind-the-scenes constraints that party leaders may have faced. In either event, we would expect the control of the portfolio that is the most salient to a party to be associated with positive electoral fortunes when they come up for reelection.

This perspective also fits well with studies of how voters form their perceptions of parties and candidates. In the face of complex political environments, attaining information about parties' detailed policy goals requires great time and effort. In practice, these costs likely lead voters to rely on the easiest symbols of policy-making based on their institutional context (Fortunato and Stevenson 2013b). Indeed, studies of heuristics suggest that voters use informational shortcuts in a range of settings (Lupia 1994; Lupia and McCubbins 1998; Kuklinski and Quirk 2001; Kuklinski et al. 2001; Lau and Redlawsk 2001; Hobolt 2007). As a clear symbol of parties' policy priorities in government, voters can easily compare the portfolios they control with the policies they emphasized in their election campaigns without any knowledge of parties' actual policy activities.

Building on past literature, we propose that the portfolios parties receive provide important signals of accountability. In the previous section, we discussed the importance of parties publicly following through on their campaign pledges. The salience of issues in parties' manifestos presumably indicates the policy areas on which voters will mostly readily expect the parties to implement policy. We contend that voters use control of a portfolio as a heuristic for perceptions of parties' policy accountability. From this perspective, parties that control their most relevant portfolio will make delivering on policy pledges more likely. Even if controlling 
the ministry does not yield a policy bonanza for the party, the mere fact of controlling it offers voters a symbol of accountability. This leads us to our first hypothesis:

H1: Parties in coalition governments controlling the portfolio they hold most salient will increase their votes in the next election.

Similarly, supporters of a party that joins a coalition in which they do not control the Prime Minister, might wonder what benefit they are getting in exchange for enabling another party to claim the most powerful position. Indeed, since only one party can control the top executive position, voters likely expect parties that do not control the Prime Minister to gain alternate, policy-focused benefits. This expectation may explain the outsized number of cabinet positions that small parties sometimes achieve beyond their seat contribution to the coalition (Falcó-Gimeno and Indridason 2013). Control of a highly salient portfolio other than the Prime Minister's office is a power symbol of just such a benefit. At the same time, controlling the Prime Minister's office may impose the lion's share of the cost of government on the party that controls it. Given the benefits of setting the cabinet's agenda, voters likely hold the Prime Minister's party to a different policy standard than parties whose main benefits are lower ranked cabinet positions. This logic motivates our second hypothesis:

$\mathrm{H} 2$ : The electoral effect of controlling the most salient ministry will be stronger for coalition parties that do not control the Prime Minister. 
Coalition negotiations revolve not only around which party controls the prime ministership, but also over the numeric allocation of cabinet positions. Gamson's law, for example, predicts that parties receive cabinet positions in proportion to the seats they give to support the cabinet (Falcó-Gimeno and Indridason 2013; Ceron 2015). Parties that do not get to control the Prime Minister's position, or their most salient policy portfolio, can compensate for these losses by controlling a larger number of ministries. We expect that control of a greater number of portfolios both can act as form of compensation for these parties to show that they received some policy benefit, and to serve as a way for parties' to have direct influence on other areas. Many portfolios' policy jurisdictions overlap such that parties can have influence on their most salient topics even when they only control a related portfolio.

Yet, parties controlling their most salient portfolio might face negative consequences for controlling too many other portfolios. The symbolic importance of controlling their most salient portfolio likely becomes muddled as the party becomes engaged in policy-making on a range of topics. Overly diverse policy appeals have negative electoral consequences for governing parties as their messages become unclear (Greene 2019). Following these logics, we propose that the total number of ministers parties control leads to alternate outcomes for parties that hold their most salient portfolio and those that do not.

H3a: The electoral effect of controlling the most salient portfolio will be weaker for parties that control more portfolios.

H3b: A larger number of portfolios will lead to an increase in the vote share at the next elections for those parties which do not control their most salient portfolios.

We propose that voters use information about parties' activities in government to evaluate their policy successes. Parties unable to control the most prominent symbols of policy 
success on their salient electoral pledges face negative electoral consequences from their supporters.

\section{Data and Methods}

Building upon previous studies of coalition behavior and election campaigns, we incorporate data on the portfolios that parties control (Bäck et al. 2011) with evidence from parties' manifestos. We combine these data with cabinet data from Strøm and Müller (2000) to produce our dataset. The combined portfolio data cover a time span of 1966-2002, and include 11 European parliamentary democracies: Austria, Belgium, Denmark, Finland, France, Germany, Ireland, Netherlands, Norway, Portugal, and Sweden.

Using the party in each election-year as the unit of analysis, we construct our dependent variable as the vote share each party receives in the election immediately following the termination of the coalition (or the first scheduled election following the coalition's formation). Electoral data come from the Parlgov database (Döring and Manow 2016). These data are party vote share from the parliamentary election year.

To construct our primary independent variable we require an indicator of parties' issue priorities prior to the coalition's formation and the distribution of portfolios between parties in the subsequent coalition. We first take indicators of the parties controlling each portfolio from the Parlgov database. In instances of caretaker governments, we take the immediately preceding governing party or governing coalition and code those parties for whichever portfolios they held prior to the caretaker government.

Like Bäck et al. (2011), we construct a salience measure based on the issues broadly connected to common cabinet positions. Following their approach, we code salience measures 
for the thirteen most common portfolio positions from the Comparative Manifestos Project (CMP) (Lehman et al. 2017). ${ }^{2}$ For each portfolio, we sum the percentage of the manifesto for all issues that would fall under the jurisdiction of the portfolio. For example, the salience score for the "Labour" portfolio is the sum of the percentage of the party's references (in the last election) to "Welfare State Expansion", "Welfare State Limitation", "Labour Groups: Positive”, and "Labour Groups: Negative".

Once we have recreated Bäck et al.’s (2011) salience scores for each coalition party in relation to each portfolio, we then construct a dummy variable that is equal to one for the portfolio that is most salient for that party. We connect this "most salient portfolio" indicator for each party with the portfolios they control in the last non-caretaker coalition. If the party controls the portfolio that it holds most salient, we code our primary variable as equal to one. If the party does not control this portfolio, then it is coded zero otherwise. For example, if a Green party discussed the environment in $60 \%$ of its platform and dedicated the rest of the platform to other topics, the environmental portfolio would be coded as the most salient. In a coalition in which the Green party was then allocated the environmental ministry, we code the party as controlling its most salient portfolio. We would then predict that this Green party would attract more votes in the pursuing election than if the party did not control the environmental minister.

In addition to a dummy variable indicating that the party controls its most salient portfolio, we also create variables to account for the other ministries the party controls to test our interactive hypotheses. In particular, we construct a dummy variable for parties controlling the prime minister in the last non-caretaker government. Likewise, we create a count of the number

\footnotetext{
${ }^{2}$ We create issue salience scores for the Foreign, Defence, Interior, Justice, Finance, Economy, Labour, Education, Health, Agriculture, Industry, Environment, and Social Affairs ministries.
} 
of total ministries the party holds (out of the thirteen coded) labeled the number of ministers. ${ }^{3}$ We present descriptive statistics for our dependent and primary independent variables in Table 1.

In addition to our primary independent variables, we account for a number of common variables used in studies of party strategy and elections. In particular, we include a measure of the Effective Number of Manifesto Issues (ENMI) to account for the breadth of the party's policy goals and policy-making successes. In the main models, this variable is interacted with a dummy variable accounting for any participation in government (see Greene 2016). ${ }^{4}$ We also construct a measure of parties' left-right positions (RILE) from the last election (time, $\mathrm{t}-1$ ) and we interact this variable with an indicator of change in the parties' position from the last to the current election based on Lowe et al.'s (2011) logged scores. We expect that parties shifting their positions towards more moderate stances will increase their vote (see Adams 1999). Furthermore, we account for the parties' percentage of seats in parliament to account for their seat contribution to the government. A Gamsonian agreement would increase the potential that larger parties control more seats and therefore also control more portfolios (and likely attract more votes) (Falcó-Gimeno and Indridason 2013). Finally, we run a series of robustness checks that substantially reduce the number of observations in our main analysis, but yield substantively similar implications. ${ }^{5}$

\footnotetext{
${ }^{3}$ This measurement strategy potentially limits our ability to make inferences for the number of ministries a party controls that are not captured by these prominent 13 positions.

${ }^{4}$ An alternative specification using an opposition party dummy variable leads to nearly identical results.

${ }^{5}$ For these robustness checks, we include economic indicators such as unemployment and change in GDP. Including these economic control variables, however, leads to a substantial decrease in N-size due to unavailable economic data from the 1960s, 1970s, and even 1980s.
} 
Table 1. Sample Statistics

\begin{tabular}{lccccc}
\hline & Mean & S.D. & Min & Max & N \\
\hline Voteshare & 17.396 & 13.7 & 0 & 51.3 & 812 \\
Controls Salient Ministry & 0.046 & .209 & 0 & 1 & 812 \\
\# of Ministries Controlled & 0.610 & 1.61 & 0 & 9 & 812 \\
Prime Minister Party & 0.180 & .384 & 0 & 1 & 812 \\
ENMI & 17.318 & 5.75 & 1.98 & 31.5 & 812 \\
Gov Party & 0.158 & .365 & 0 & 1 & 812 \\
RILE (log) & -0.799 & .874 & -4.36 & 1.1 & 812 \\
Parliamentary Seatshare & -0.409 & .208 & -.693 & .088 & 812 \\
\hline
\end{tabular}

\section{Results}

Given the cross-sectional time series nature of our data, we use panel corrected standard errors with a lagged dependent variable in our main analysis. ${ }^{6}$ The results from our analysis are robust to a range of modeling choices. ${ }^{7}$ Table 2 presents the results of our primary analysis.

\footnotetext{
${ }^{6}$ Augmented- Dickey Fuller and Phillips-Perron tests both reject the null hypothesis that all panels contain a unit root at the $95 \%$ level or greater. We nonetheless present results with a lagged dependent variable. Limiting the tests to the country level, some panels fail to reject the null hypothesis that all panels contain unit-roots.

${ }^{7}$ In particular, we have performed the analysis using OLS with robust standard errors clustered on the party with and without a lagged dependent variable. We also performed mixed effects models including random variance at the country and election levels and models with panel corrected standard errors including fixed effects for the country level. In each set of comparisons, models with the lagged DV perform better than those without as determined by measures of fit such as the Root Mean Squared Error, the R-Squared and Chi-Squared values.
} 
Table 2: Regression Analyses

\begin{tabular}{|c|c|c|c|c|}
\hline & $\begin{array}{c}(1) \\
\text { Simple }\end{array}$ & $\begin{array}{c}(2) \\
\text { Interactions }\end{array}$ & $\begin{array}{l}\text { (3) } \\
\text { Full }\end{array}$ & $\begin{array}{c}\text { (4) } \\
\text { Government } \\
\text { Subsample }^{8}\end{array}$ \\
\hline Controls Salient Ministry & $\begin{array}{l}-0.621 \\
(1.005)\end{array}$ & $\begin{array}{c}2.931 \\
(2.605)\end{array}$ & $\begin{array}{l}5.500^{*} \\
(2.409)\end{array}$ & $\begin{array}{l}\mathbf{6 . 8 5 6}^{*} \\
(\mathbf{2 . 7 5 5 )}\end{array}$ \\
\hline \# of Ministries Held & $\begin{array}{l}-0.033 \\
(0.129)\end{array}$ & $\begin{array}{c}0.124 \\
(0.123)\end{array}$ & $\begin{array}{l}0.682^{* *} \\
(0.219)\end{array}$ & $\begin{array}{l}0.967^{*} \\
(0.422)\end{array}$ \\
\hline Prime Minister Party & $\begin{array}{c}-0.813^{+} \\
(0.442)\end{array}$ & $\begin{array}{l}-0.717 \\
(0.522)\end{array}$ & $\begin{array}{c}-0.555 \\
(0.509)\end{array}$ & $\begin{array}{c}3.361 \\
(2.321)\end{array}$ \\
\hline Salient Min * \# of Ministries Held & & $\begin{array}{l}-1.031^{*} \\
(0.477)\end{array}$ & $\begin{array}{c}-1.623^{* * *} \\
(0.474)\end{array}$ & $\begin{array}{l}-1.823^{*} \\
(0.694)\end{array}$ \\
\hline PM * \# of Ministries Held & & $\begin{array}{l}-0.293 \\
(0.217)\end{array}$ & $\begin{array}{l}-0.480^{*} \\
(0.206)\end{array}$ & $\begin{array}{l}-1.211^{*} \\
(0.456)\end{array}$ \\
\hline PM * Controls Salient Ministry & & $\begin{array}{l}-3.544 \\
(5.721)\end{array}$ & $\begin{array}{l}-3.741 \\
(5.766)\end{array}$ & $\begin{array}{l}-7.211 \\
(7.876)\end{array}$ \\
\hline PM * Salient Min * \# of Mins & & $\begin{array}{c}1.265 \\
(0.996)\end{array}$ & $\begin{array}{c}1.455 \\
(1.016)\end{array}$ & $\begin{array}{c}2.108 \\
(1.336)\end{array}$ \\
\hline Gov Party & & & $\begin{array}{l}-2.535 \\
(3.112)\end{array}$ & \\
\hline ENMI & & & $\begin{array}{c}0.010 \\
(0.027)\end{array}$ & $\begin{array}{c}0.049 \\
(0.145)\end{array}$ \\
\hline Gov Party * ENMI & & & $\begin{array}{c}0.010 \\
(0.147)\end{array}$ & \\
\hline$\triangle \mathrm{RILE}$ & & & $\begin{array}{c}0.514 \\
(0.325)\end{array}$ & $\begin{array}{l}2.555^{*} \\
(1.040)\end{array}$ \\
\hline RILE & & & $\begin{array}{c}0.018 \\
(0.170)\end{array}$ & $\begin{array}{c}0.860 \\
(0.960)\end{array}$ \\
\hline$\triangle \mathrm{RILE} * \mathrm{RILE}$ & & & $\begin{array}{l}0.399^{* * *} \\
(0.152)\end{array}$ & $\begin{array}{l}1.822^{* *} \\
(0.601)\end{array}$ \\
\hline Percent Seatst-1 & & & $\begin{array}{c}-5.710^{+} \\
(3.360)\end{array}$ & $\begin{array}{l}-27.879 \\
(23.656)\end{array}$ \\
\hline Percent Vote ${ }_{t-1}$ & $\begin{array}{c}0.962^{* * *} \\
(0.034)\end{array}$ & $\begin{array}{c}0.964^{* * * *} \\
(0.036)\end{array}$ & $\begin{array}{l}1.044^{* * *} \\
(0.045)\end{array}$ & $\begin{array}{l}1.324^{* * * *} \\
(0.297)\end{array}$ \\
\hline Constant & $\begin{array}{c}0.612 \\
(0.528)\end{array}$ & $\begin{array}{c}0.545 \\
(0.555)\end{array}$ & $\begin{array}{l}-3.222^{+} \\
(1.891)\end{array}$ & $\begin{array}{c}-20.097 \\
(17.376)\end{array}$ \\
\hline
\end{tabular}

\footnotetext{
${ }^{8}$ There are insufficient panels to use panel corrected standard errors in the government party subsample. Instead, we present the results of ordinary least squares regression with robust errors clustered on the party id.
} 


\begin{tabular}{lcccc}
\hline chi2 & 919.690 & 1782.350 & 16289.227 & \\
RMSE & 4.140 & 4.138 & 4.124 & 4.558 \\
$N$ & 812 & 812 & 812 & 128 \\
\hline
\end{tabular}

Standard errors in parentheses

Note: The Dependent variable is the Percentage Vote.

${ }^{+} p<0.10,{ }^{*} p<0.05,{ }^{* *} p<0.01,{ }^{* * *} p<0.001$

In our first hypothesis, we predict that parties that control the portfolio linked to their most salient issues benefit in the consequent election. The coefficient for controlling the party's most salient minister is negative and not statistically different from zero in Model 1. The null results in Table 2 for this initial unconditional hypothesis suggest a more complicated relationship.

The results become more complicated once the models account for the moderating effect of controlling the Prime Minister (H2) and the number of ministries (H3a and H3b). In particular, the constitutive term for controlling the party's most salient portfolio is positive and becomes statistically different from zero in the full model (and the government party subsample) at the 95\% level. Furthermore, interactions with the Prime Minister and the number of ministries variables suggest differences between parties dependent on how many portfolios they control.

Interestingly, these findings demonstrate that there is a balancing act between achieving policy and office benefits from joining the government and also being electorally rewarded for controlling the portfolio on the party's most prominent policy areas or procuring a larger number of ministries. Junior coalition parties that acquire a diverse set of portfolios or their most salient portfolio benefit as a junior coalition partner can compensate for not controlling their most salient portfolio by controlling a larger number of ministries. The interactions further indicate a clearer benefit for junior coalition partners, rather than those controlling the prime minister's position. 
The control variables in Model 3 and Model 4 also provide some interesting evidence. The coefficients for parties' RILE in the last election ( $t-1)$ and its interaction with the change in RILE (t-1, t) suggest some benefit from changing positions in Model 3 and Model 4.

Intriguingly, the marginal effects for these variables based on Model 4 show that conservative parties actually benefit from moving more to the right, whereas more ideologically left parties gain no benefit from changing RILE. Likewise, in Model 3, parties controlling more seats decrease their vote in the next election. There is no significant effect of ENMI in the model and additional robustness checks including measures for GDP change and unemployment yield comparable results, although the number of observations drops substantially due to missing data from the World Bank.

Due to the three way interaction, we illustrate the marginal effect of controlling the party's most salient portfolio in Figure 1 over the number of ministers for the Prime Minister's party and other coalition parties based on the government party subsample. ${ }^{9}$ For both sets of parties, there is an initial positive effect for parties controlling their most salient issues. For the Prime Minister's party, the effect remains positive over the range of the number of ministers, but the $95 \%$ confidence intervals overlap with zero when parties control more than 2 ministers (in addition to the Prime Minister). The marginal effect for other coalition parties is initially positive. Coalition parties with a small number of ministers gain electorally for controlling their most salient portfolio. Yet, the effect becomes negative once the party controls more than four ministers and the $95 \%$ confidence intervals exclude zero for coalitions controlling more than six ministers. This suggests that parties controlling their most salient portfolio and a large number of ministers, but not the Prime Minister might actually be punished in the elections that follow.

\section{Figure 1. Marginal effect of the number of ministers when the party controls the most}

\footnotetext{
${ }^{9}$ The graphical results from the full model are nearly identical.
} 
important portfolio.
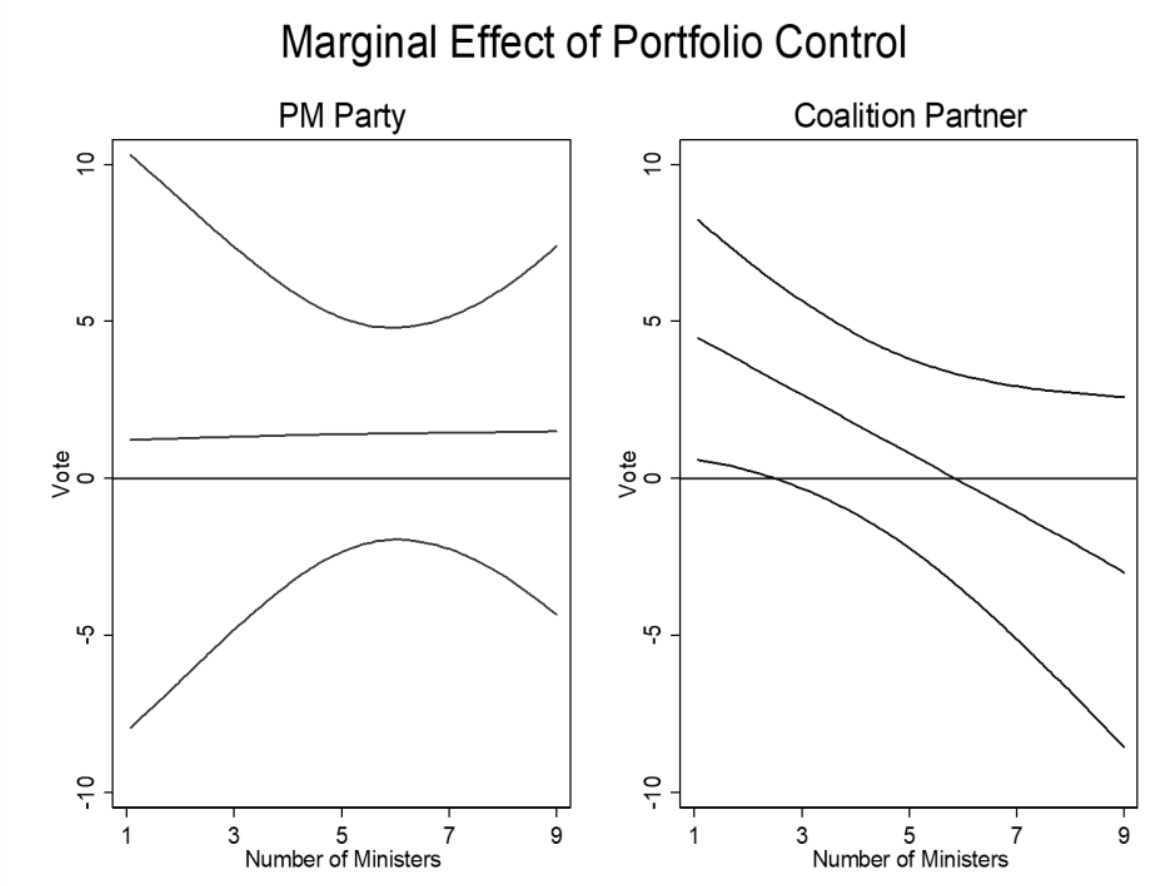

We further consider our second hypothesis, that controlling the Prime Minister's position will decrease the positive effect of holding the party's most salient portfolio in Figure 2 . The marginal effect of controlling the Prime Minister over the range of the number of ministers is decreasing for those parties not controlling the most salient minister and increasing for those that do. The effect is only statistically different from zero for those parties not controlling their most salient portfolio that control a larger number of ministers as can be seen from the $95 \%$ confidence intervals in Figure 2.

Figure 2. Marginal effect of the number of ministers when the party does not control the 
most important portfolio.

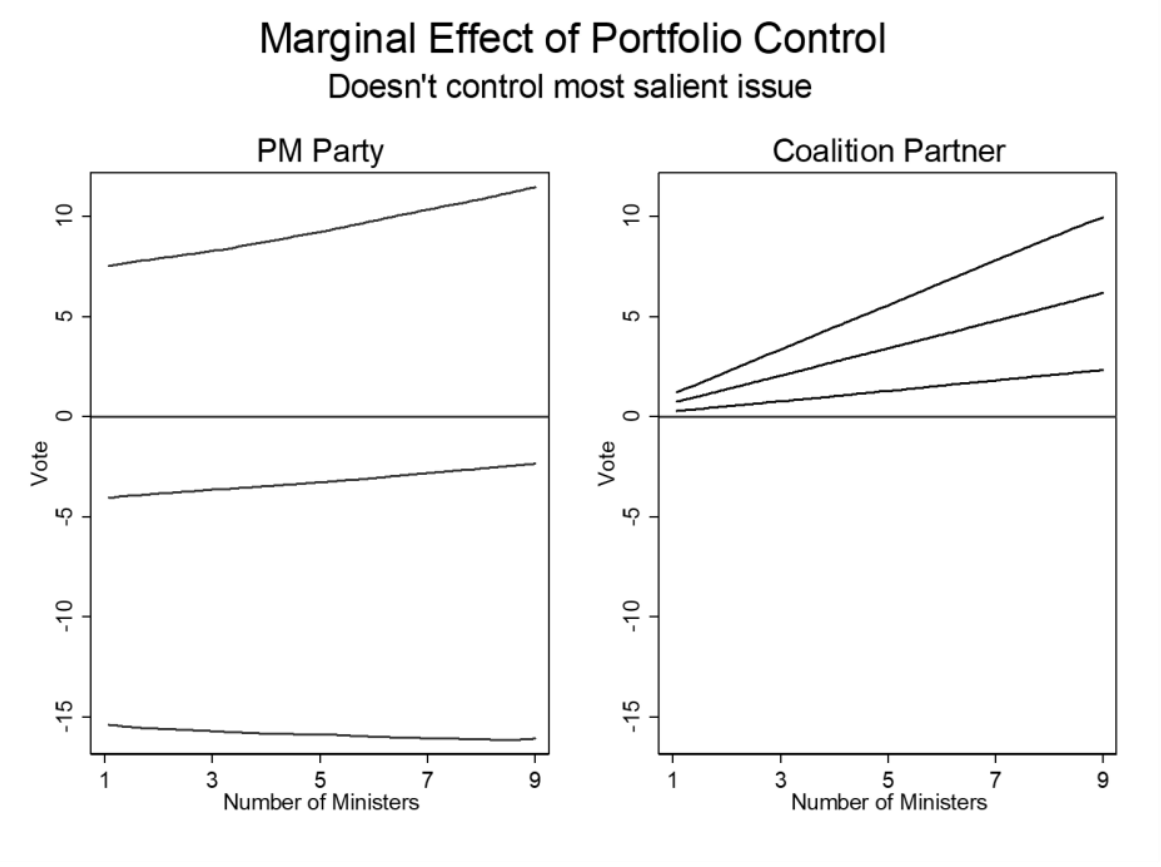

Finally, the third hypothesis predicts that parties with more ministers decrease the positive effect of controlling the most salient portfolio (H3a), but will increase the party's vote overall $(\mathrm{H} 3 \mathrm{~b})$. The results suggest mixed evidence as shown in the marginal effect in Figure 3. In particular, the marginal effect is never significant for the Prime Minister's party (not shown), but differs according to whether the party controls the most salient portfolio or not. Consistent with the logic of the two part hypothesis, the marginal effect of controlling more ministers is negative when the party controls its most salient portfolio (although the $95 \%$ confidence intervals cover the null effect), but positive otherwise. The two effects are statistically different from each other at the $99.9 \%$ confidence level. Parties that do not control the Prime Minister and do not get their most preferred portfolio get some positive electoral benefit for controlling more ministers overall (nearly one percent for each additional minister), whereas those controlling their most salient portfolio are punished.

Figure 3. Marginal effect of the number of ministers when the party does not control the 
most important portfolio.
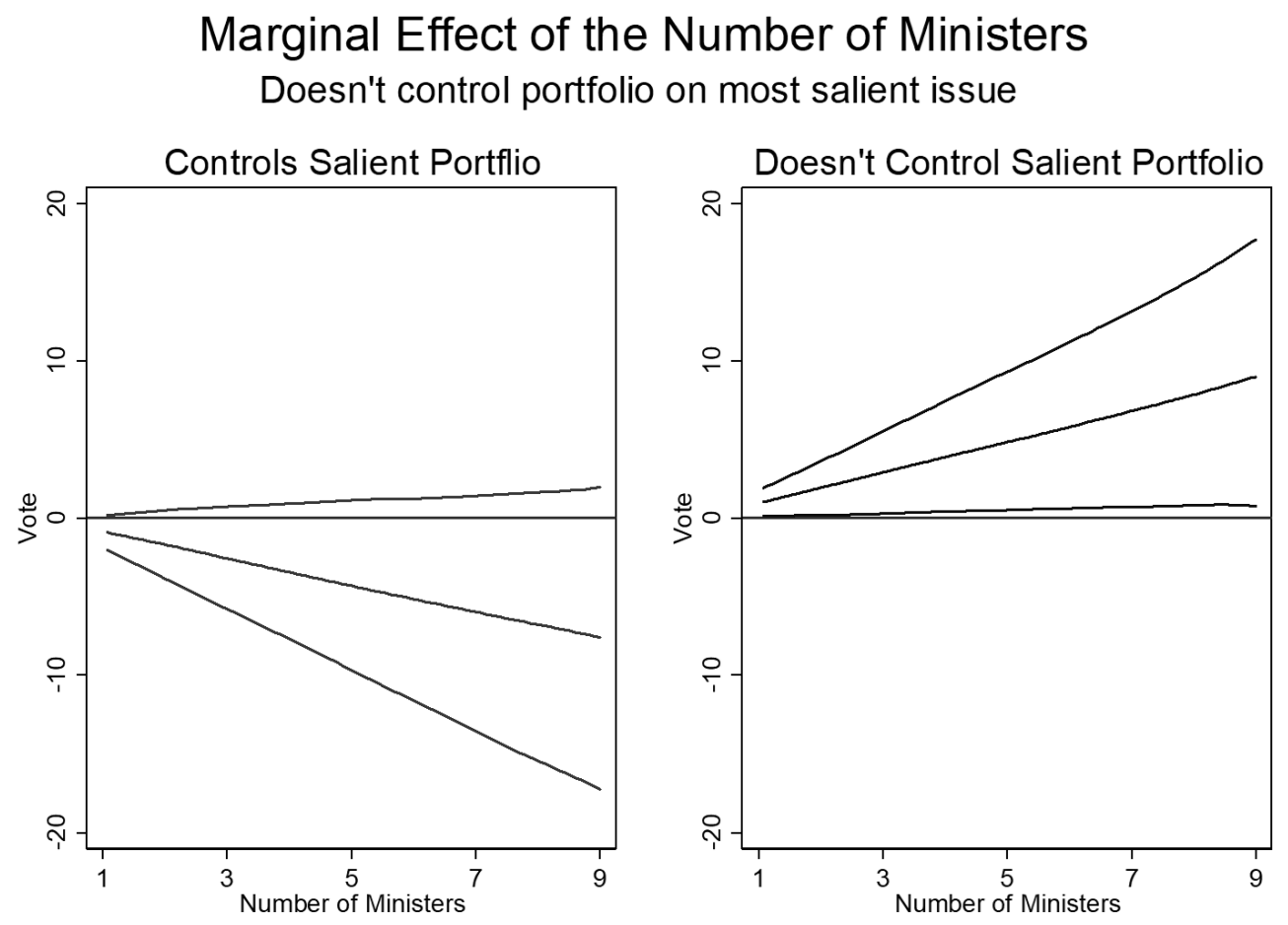

\section{Conclusion}

We propose that voters hold governing parties accountable for their policy statements.

Despite the challenges of attributing policy responsibility to parties in coalition settings (see Fortunato and Stevenson 2013), we find electoral evidence that voters use simple symbols to evaluate parties' actions. We find evidence that controlling the most salient portfolio yields electoral benefits for parties. Our empirical examination shows that this effect is stronger for junior coalition partners than for parties that control the Prime Minister. Lastly, we find that controlling more ministries yields an electoral benefit when that party does not control its most salient portfolio. In sum, we find that controlling the most salient portfolio is something of a substitute for controlling a lot of ministries for junior coalition partners. These findings are no 
less important for being intuitive. In Table 3, we summarize our findings for this article's

hypotheses.

Table 3: Hypothesis Summary

\begin{tabular}{|l|c|c|l|}
\hline Hypothesis & $\begin{array}{l}\text { Predicted } \\
\text { Outcome }\end{array}$ & $\begin{array}{l}\text { Actual } \\
\text { Outcome }\end{array}$ & Explanation \\
\hline $\begin{array}{l}\text { H1: Parties in coalition governments } \\
\text { controlling the portfolio they hold } \\
\text { most salient will increase their votes } \\
\text { in the next election. }\end{array}$ & + & $\begin{array}{c}\text { Not } \\
\text { Supported }\end{array}$ & $\begin{array}{l}\text { The electoral effect of simply } \\
\text { controlling the party's most } \\
\text { salient portfolio is more } \\
\text { nuanced than predicted, and } \\
\text { requires further model } \\
\text { specification. }\end{array}$ \\
\hline $\begin{array}{l}\text { H2: The electoral effect of } \\
\text { controlling the most salient manifest } \\
\text { will be stronger for coalition parties } \\
\text { that do not control the Prime Minister. }\end{array}$ & + & Supported & $\begin{array}{l}\text { When controlling for holding } \\
\text { the Prime Minister portfolio, a } \\
\text { positive coefficient that is } \\
\text { statistically significant emerges. } \\
\text { This suggests that holding } \\
\text { salient portfolios will be } \\
\text { electorally more important for } \\
\text { minor coalition partners. }\end{array}$ \\
\hline $\begin{array}{l}\text { H3a: The electoral effect of } \\
\text { controlling the most salient portfolio } \\
\text { will be weaker for parties that control } \\
\text { more portfolios. }\end{array}$ & + & Supported & $\begin{array}{l}\text { Prime Minister parties receive } \\
\text { an electoral boost until they } \\
\text { reach 3 total portfolios held, at } \\
\text { which point there is a negative } \\
\text { marginal effect. For minor } \\
\text { coalition partners, this portfolio } \\
\text { threshold is 4. }\end{array}$ \\
\hline $\begin{array}{l}\text { H3b: Parties controlling more } \\
\text { portfolios will increase their votes in } \\
\text { the next election. }\end{array}$ & + & Partially & $\begin{array}{l}\text { For parties that do not hold their } \\
\text { most salient portfolio, there is a } \\
\text { positive electoral effect to } \\
\text { holding a higher number of total } \\
\text { portfolios. For parties that hold } \\
\text { their most salient portfolio, this } \\
\text { electoral boost is not observed. }\end{array}$ \\
\hline
\end{tabular}

Our findings suggest new research questions about government formation. If potential coalition partners expect electoral benefits from controlling their most salient portfolio they may be willing to forgo some quantity of portfolios. Indeed, they should use their bargaining leverage to focus specifically on the portfolios that benefit them most. Conversely, when two smaller 
parties are both considering a coalition and put the same salience on some portfolio it could complicate the government formation process. We believe that our findings can complement ongoing research into coalition agreements (see Strøm et al. 2008; The European Representative Democracy Data Archive 2019). In particular, our findings inform coalition partners of the possible electoral benefits of joining a coalition even in light of the very real electoral costs that coalition partners could face in subsequent elections (see Klüver and Spoon 2016).

Like the study of political heuristics in other settings, the usage of simple symbols to evaluate governing coalition parties' policy accountability and responsiveness creates a conundrum for smaller parties. Their limited size means they can only negotiate for a small number of cabinet positions. But their future electoral success depends on, in part, controlling enough positions on their most salient issues. The results presented in this paper suggest that smaller parties might prefer not joining coalitions unless they can negotiate for a disproportionate share of cabinet positions. Furthermore, from an electoral standpoint, parties controlling the Prime Minister face few negative electoral consequences from this behavior. If they desire to continue the coalition, their best strategy may be to give in to smaller party demands.

At the most basic level of voters' perceptions of party success, small parties who do decide to join a governing coalition are able to point to the number of portfolios they hold as evidence of their party's governing success. Amplifying this effect is the salience of the portfolios held by these smaller parties. If this is indeed the case, then our findings help to shed light on small party coalition members' strategies for sustaining their governing success in subsequent elections and coalition formation. 


\section{Bibliography}

Adams, J., 1999. Multiparty spatial competition with probabilistic voting. Public Choice, 99(34), pp.259-274.

Axelrod, R.M., 1970. Conflict of interest: A theory of divergent goals with applications to politics (pp. 3511-3511). Chicago, IL: Markham Publishing Company.

Bäck, H., Debus, M. and Dumont, P., 2011. Who gets what in coalition governments? Predictors of portfolio allocation in parliamentary democracies. European Journal of Political Research, 50(4), pp.441-478.

Bélanger, É. and Meguid, B.M., 2008. Issue salience, issue ownership, and issue-based vote choice. Electoral Studies, 27(3), pp.477-491.

Bergman, T. and Strom, K. eds., 2011. The Madisonian turn: Political parties and parliamentary democracy in Nordic Europe. University of Michigan Press.

Bevan, S. and Greene, Z., 2016. Looking for the party? The effects of partisan change on issue attention in UK Acts of Parliament. European Political Science Review, 8(1), pp.49-72.

-----. 2018. Cross-national partisan effects on agenda stability. Journal of European Public Policy, 25(4), pp.586-605.

Robertson, D.B., 1976. A theory of party competition (p. 80). London: Wiley.

Carey, J.M., 2007. Competing principals, political institutions, and party unity in legislative voting. American Journal of Political Science, 51(1), pp.92-107.

Carmines, E.G. and Stimson, J.A., 1986. On the structure and sequence of issue evolution. American Political Science Review, 80(3), pp.901-920.

Carroll, R. and Cox, G.W., 2007. The logic of Gamson's Law: Pre-election coalitions and portfolio allocations. American Journal of Political Science, 51(2), pp.300-313.

Cole, A., 2005. Old right or new right? The ideological positioning of parties of the far right. European Journal of Political Research, 44(2), pp.203-230.

De Vries, C.E. and Hobolt, S.B., 2012. When dimensions collide: The electoral success of issue entrepreneurs. European Union Politics, 13(2), pp.246-268.

Debus, M. and Müller, J., 2014. Expected utility or learned familiarity? The formation of voters' coalition preferences. Electoral Studies, 34, pp.54-67.

Debus, M., Stegmaier, M. and Tosun, J., 2014. Economic voting under coalition governments: Evidence from Germany. Political Science Research and Methods, 2(1), pp.49-67. 
Döring, H. and Manow, P.. 2016. Parliaments and governments database (ParlGov): Information on parties, elections and cabinets in modern democracies.

Downs, A., 1957. An economic theory of political action in a democracy. Journal of political economy, 65(2), pp.135-150.

Druckman, J.N. and Warwick, P.V., 2005. The missing piece: Measuring portfolio salience in Western European parliamentary democracies. European Journal of Political Research, 44(1), pp.17-42.

Egan, P.J., 2013. Partisan priorities: How issue ownership drives and distorts American politics. Cambridge University Press.

Eichorst, J., 2014. Explaining variation in coalition agreements: The electoral and policy motivations for drafting agreements. European Journal of Political Research, 53(1), pp.98-115.

Falcó-Gimeno, A. and Indridason, I.H., 2013. Uncertainty, complexity, and Gamson's Law: Comparing coalition formation in Western Europe. West European Politics, 36(1), pp.221-247.

Fortunato, D. and Stevenson, R.T., 2013. Perceptions of partisan ideologies: The effect of coalition participation. American Journal of Political Science, 57(2), pp.459-477.

Green, J., 2007. When voters and parties agree: Valence issues and party competition. Political Studies, 55(3), pp.629-655.

-----, 2011. A test of core vote theories: The British Conservatives, 1997-2005. British Journal of Political Science, 41(4), pp.735-764.

Green, J. and Jennings, W., 2012. The dynamics of issue competence and vote for parties in and out of power: An analysis of valence in Britain, 1979-1997. European Journal of Political Research, 51(4), pp.469-503.

Green-Pedersen, C., 2007. The growing importance of issue competition: The changing nature of party competition in Western Europe. Political studies, 55(3), pp.607-628.

Green-Pedersen, C. and Mortensen, P.B., 2009. Coding of Party Manifestos and PMs Speeches in Denmark. Aarhus: Department of Political Science, University of Aarhus.

Greene, Z., 2016. Competing on the issues: How experience in government and economic conditions influence the scope of parties' policy messages. Party Politics, 22(6), pp.809822.

-----, 2017. Working through the issues: how issue diversity and ideological disagreement 
influence coalition duration. European Political Science Review, 9(4), pp.561-585.

Greene, Z. and Jensen, C.B., 2016. Manifestos, salience and junior ministerial appointments. Party Politics, 22(3), pp.382-392.

-----, 2018. Ruling divided: Disagreement, issue salience, and portfolio allocation. Party Politics, 24(6), pp.640-651.

Greene, Z. and O'Brien, D.Z., 2016. Diverse parties, diverse agendas? Female politicians and the parliamentary party's role in platform formation. European Journal of Political Research, 55(3), pp.435-453.

Hellwig, T., 2012. Constructing accountability: Party position taking and economic voting. Comparative Political Studies, 45(1), pp.91-118.

Hjermitslev, I.B., 2018. The electoral cost of coalition participation: Can anyone escape?. Party Politics, p.1354068818794216.

Hobolt, S.B., 2007. Taking cues on Europe? Voter competence and party endorsements in referendums on European integration. European Journal of Political Research, 46(2), pp.151-182.

Indridason, I.H. and Kam, C., 2008. Cabinet reshuffles and ministerial drift. British Journal of Political Science, 38(4), pp.621-656.

Indridason, I.H. and Kristinsson, G.H., 2013. Making words count: Coalition agreements and cabinet management. European Journal of Political Research, 52(6), pp.822-846.

Kim, D.H. and Loewenberg, G., 2005. The role of parliamentary committees in coalition governments: Keeping tabs on coalition partners in the German Bundestag. Comparative Political Studies, 38(9), pp.1104-1129.

Klüver, H. and Spoon, J.J., 2016. Helping or Hurting? How Governing as a Junior Coalition Partner Influences Electoral Outcomes.

Kuklinski, J.H. and Quirk, P.J., 2001. Conceptual foundations of citizen competence. Political Behavior, 23(3), pp.285-311.

Kuklinski, J.H., Quirk, P.J., Jerit, J. and Rich, R.F., 2001. The political environment and citizen competence. American Journal of Political Science, 45(2), pp.410-424.

Lau, R.R. and Redlawsk, D.P., 2001. Advantages and disadvantages of cognitive heuristics in political decision making. American Journal of Political Science, pp.951-971.

Laver, M. and Schofield, N., 1998. Multiparty government: The politics of coalition in Europe. University of Michigan Press. 
Laver, M.J., Laver, M. and Shepsle, K.A., 1996. Making and breaking governments: Cabinets and legislatures in parliamentary democracies. Cambridge University Press.

Lehmann, P., Matthieß, T., Merz, N., Regel, S. and Werner, A., 2017. Manifesto Corpus. Version: 2017-2. Berlin: WZB Berlin Social Science Center.

Lewis-Beck, M.S., 1986. Comparative Economic Voting: Britain, France, Germany, Italy. American Journal of Political Science, pp.315-346.

Lewis-Beck, M.S. and Stegmaier, M., 2000. Economic determinants of electoral outcomes. Annual review of political science, 3(1), pp.183-219.

-----, 2013. The VP-function revisited: a survey of the literature on vote and popularity functions after over 40 years. Public Choice, 157(3-4), pp.367-385.

Lipsmeyer, C.S. and Pierce, H.N., 2011. The eyes that bind: Junior ministers as oversight mechanisms in coalition governments. The Journal of Politics, 73(4), pp.1152-1164.

Lowe, W., Benoit, K., Mikhaylov, S. and Laver, M., 2011. Scaling policy preferences from coded political texts. Legislative studies quarterly, 36(1), pp.123-155.

Lupia, A., 1994. Shortcuts versus encyclopedias: Information and voting behavior in California insurance reform elections. American Political Science Review, 88(1), pp.63-76.

Lupia, A. and McCubbins, M.D., 1994. Who controls? Information and the structure of legislative decision making. Legislative Studies Quarterly, pp.361-384.

Mansergh, L. and Thomson, R., 2007. Election pledges, party competition, and policymaking. Comparative Politics, pp.311-329.

Martin, S., 2016. Policy, office and votes: the electoral value of ministerial office. British Journal of Political Science, 46(2), pp.281-296.

Meguid, B.M., 2005. Competition between unequals: The role of mainstream party strategy in niche party success. American Political Science Review, 99(3), pp.347-359.

Müller, W.C. and Strom, K. eds., 2003. Coalition governments in western Europe. Oxford University Press on Demand.

Nadeau, R., Foucault, M. and Lewis-Beck, M.S., 2010. Patrimonial economic voting: legislative elections in France. West European Politics, 33(6), pp.1261-1277.

Nannestad, P. and Paldam, M., 1994. The VP-function: A survey of the literature on vote and popularity functions after 25 years. Public Choice, 79(3-4), pp.213-245. 
Paldam, M., 1986. The distribution of election results and the two explanations of the cost of ruling. European Journal of Political Economy, 2(1), pp.5-24.

Palmer, H.D. and Whitten, G.D., 1999. The electoral impact of unexpected inflation and economic growth. British Journal of Political Science, 29(4), pp.623-639.

Petrocik, J.R., 1996. Issue ownership in presidential elections, with a 1980 case study. American journal of political science, 40, pp.825-850.

Proksch, S.O. and Slapin, J.B., 2006. Institutions and coalition formation: The German election of 2005. West European Politics, 29(3), pp.540-559.

Riker, W.H., 1980. Implications from the Disequilibrium of Majority Rule for the Study of Institutions. American Political Science Review, 74(2), pp.432-446.

Rose, R. and Mackie, T., 1983. "Incumbency in Government: Liability or Asset?" Western European Party Systems. Beverly Hills and London: Sage Publications: 115-38.

Soroka, S.N. and Wlezien, C., 2010. Degrees of democracy: Politics, public opinion, and policy. Cambridge University Press.

Spoon, J.J. and Klüver, H., 2014. Do parties respond? How electoral context influences party responsiveness. Electoral Studies, 35, pp.48-60.

Strom, K., 1984. Minority governments in parliamentary democracies: The rationality of nonwinning cabinet solutions. Comparative Political Studies, 17(2), pp.199-227.

-----, 1990. Minority government and majority rule. Cambridge University Press.

Strøm, K., Müller, W.C. and Bergman, T., 2008. Cabinets and coalition bargaining: the democractic life cycle in Western Europe. Oxford University Press.

The European Representative Democracy Data Archive. 2019. https://erdda.org/ (Date Accessed 6 September 2019).

Thies, M.F., 2001. Keeping tabs on partners: The logic of delegation in coalition governments. American Journal of Political Science, pp.580-598.

Thomson, R., 2011. Citizens' evaluations of the fulfillment of election pledges: Evidence from Ireland. The Journal of Politics, 73(1), pp.187-201.

Tresch, A., Sciarini, P. and Varone, F., 2013. The relationship between media and political agendas: Variations across decision-making phases. West European Politics, 36(5), pp.897-918.

Vavreck, L., 2009. The message matters: The economy and presidential campaigns. Princeton 
University Press.

Wagner, M. and Meyer, T.M., 2014. Which issues do parties emphasise? Salience strategies and party organisation in multiparty systems. West European Politics, 37(5), pp.1019-1045.

Walgrave, S., Lefevere, J. and Tresch, A., 2012. The associative dimension of issue ownership. Public Opinion Quarterly, 76(4), pp.771-782.

-----, 2014. The limits of issue ownership dynamics: The constraining effect of party preference. Journal of Elections, Public Opinion \& Parties, 24(1), pp.1-19.

Warwick, P.V. and Druckman, J.N., 2001. Portfolio salience and the proportionality of payoffs in coalition governments. British journal of political Science, 31(4), pp.627-649.

Williams, L.K., Seki, K. and Whitten, G.D., 2016. You've got some explaining to do the influence of economic conditions and spatial competition on party strategy. Political Science Research and Methods, 4(1), pp.47-63.

Williams, C. and Spoon, J.J., 2015. Differentiated party response: The effect of Euroskeptic public opinion on party positions. European Union Politics, 16(2), pp.176-193.

The World Bank. 2017. World Development Indicators. http://data.worldbank.org/datacatalog/world-development-indicators/ (date accessed March 2017). 